\author{
Maria Szczepska-Pustkowska \\ Uniwersytet Gdański \\ pedmsp@ug.edu.pl \\ Longina Strumska-Cylwik \\ Uniwersytet Gdański \\ 1.strumska@ug.edu.pl
}

Malgorzata Lewartowska-Zychowicz

Uniwersytet Gdański

pedmlz@ug.edu.pl

\title{
Makarenkowskie odczyty o wychowaniu dla rodziców w optyce Foucaultowskiej kategorii urządzania
}

\section{Summary}

Makarenko's readings on upbringing for parents in the perspective of Foucault's governmentality category

The subject of our interest is the rhetoric of Makarenko's readings/interpretations of upbringing designated for parents. We would like to subject it to consideration in the prospect/perspective of Foucault's governmentality category, understood as a specific metacategory/joint category connecting the axes of power (the Soviet power), knowledge (political economy), and the subject (homo sovieticus). Applying the governmentality category provides for the possibility of attempting to reconstruct traces of tangle/discursive relations and undiscursive elements of the policy of arranging a family which is a component of a broader policy of the Soviet state aimed at "forging" the new Soviet man. In this context, we will recognize Makarenko's pedagogy as a kind of conceptualization and implementation of the policy of the Soviet state at the family level, having the goal of shaping a man of collective mentality, completely subordinated to the Soviet state, with standardized and ideologized consciousness.

Słowa kluczowe: Anton Makarenko, homo sovieticus, urządzanie

Keywords: Anton Makarenko, homo sovieticus, governmentality

\section{Wprowadzenie}

Celem tekstu jest analiza retoryki wypowiedzi Antoniego Makarenki skierowanej do rodziców w Knigie dla roditielej wydanej w Moskwie w 1937 roku (Makarenko 1956), w perspektywie Foucaultowskiej kategorii urządzania, rozumianej jako swoista „metakategoria”/ 
„kategoria zbiorcza” (zob. Ostrowicka 2015: 11) łącząca osie władzy (sowieckiej), wiedzy (ekonomii politycznej) i podmiotu (homo sovieticus). Wykorzystanie w podjętych analizach tej kategorii - jak zakładamy - pozwoli nam odsłonić relację między rządzeniem a rozumem urządzającym, egzemplifikowaną przez Makarenkowskie odczyty. Sposób myślenia i sposób mówienia traktujemy bowiem jako zakorzenioną w dyskursie część praktyki rządzenia.

\section{Homo sovieticus - szkic portretu}

Znawcy tematyki Rewolucji Październikowej zgodni są co do tego, że zapoczątkowała ona nową erę w dziejach. Jednak jej ocena nie jest już tak oczywista i nadal stanowi przedmiot sporów. Jedni bowiem „uważają, że był to »krok naprzód«, drudzy - że »krok w tył«, trzeci - że »krok w miejscu«. Wszyscy jednak przyznają, że w 1917 r. po raz pierwszy dokonano rewolucji, której celem było nie tylko zawładnięcie "maszyną państwową«, jak wyrażał się Lenin, ale stworzenie idealnego społeczeństwa, zbudowanie sytemu politycznego, gospodarczego i społecznego, jakiego ludzkość dotychczas nie znała. „Celem przewrotu październikowego było urzeczywistnienie Projektu mającego doprowadzić do Celu. Po zdobyciu władzy autorzy projektu wiedzieli już, że cel osiągną tylko wówczas, jeśli stworzą nowego człowieka" (Bucharin, za: Heller 1988: 9).

By urzeczywistnić ów cel, zarysowano portret nowego człowieka i uruchomiono instrumenty, mające służyć planowanej przemianie. Od pierwszych dni po zdobyciu władzy zabrano się do wychowawczej „obróbki materiału ludzkiego epoki kapitalistycznej”, by po 60 latach w książce Ludzie sowieccy stwierdzić z dumą, że Związek Sowiecki jest pierwszym na ziemi królestwem wolności człowieka pracy i ojczyzną homo sovieticusa: „Homo sapiens ewoluował przez miliony lat, oczyszczanie go ze zła trwało lat sześćdziesiąt i oto w Związku Sowieckim zrodził się wyższy typ homo sapiens - homo sovieticus, nowy gatunek biologiczny" (Zinowiew 1974: 3).

Na przestrzeni czasu model człowieka sowieckiego zmieniał się. W latach 20. obowiązywał model „rewolucjonisty - burzyciela starego porządku” (niezłomnego komisarza ludowego i twardego czekisty), po nim nadszedł „budowniczy nowego ładu” (,człowiek przemysłowy”, „naukowo-organizacyjny” i uskomczeł czyli „udoskonalony człowiek komunistyczny"), aż wreszcie zrodził się ostateczny ideał - człowiek uważający się za „śrubkę" w maszynie państwowej (Heller 1988: 11-12).

Najważniejszą cechą modelu człowieka sowieckiego uczyniono uczucie przynależności do państwa, do kolektywu, poczucie bycia częścią machiny państwowej. Jewgienij Zamiatin pisał: „Dwie szale wagi: na jednej gram, na drugiej tona, na jednej $» j a \lll$, na drugiej »my«, Jedyne Państwo. Czyż nie jest jasne, że przypuszczać, iż »ja« może mieć jakieś "prawa« w obliczu Państwa to tyle samo, co przypuszczać, że gram może zrównoważyć tonę? Stąd podział: tona ma prawa, gram obowiązki; i naturalna droga od nicości do wielkości: zapomnij, żeś gramem i poczuj się milionową cząstką tony” (Zamiatin 1967: 100). Proces prowadzący do owego scalenia określano zapożyczonym z metalurgii terminem „przekucie” (Zinowiew 1974: 190 i nn.). 
Szkic portretu człowieka sowieckiego odnajdujemy we Wstępie do pracy zbiorowej Ludzie sowieccy. Najważniejszą cechą człowieka sowieckiego jest komunistyczna ideowość, która wyraża się w „całym jego światopoglądzie, w jasnym widzeniu ideału, w żarliwym wcielaniu go w życie" (Zinowiew 1974: 190). Człowiek sowiecki to człowiek pracy i kolektywu, bezgranicznie oddany socjalistycznej ojczyźnie. Ma standardową zideologizowaną świadomość, gotów jest ponosić ofiary oraz poświęcić innych w ofierze. Wyznaje wyższe ideały i z zaangażowaniem wciela w życie zasady rewolucyjne. Homo$\operatorname{sos}^{1}$ gotów jest stawić czoła trudnościom, całą duszą popiera działania władz; stara się przeszkodzić tym, którzy naruszają normy postępowania (Zinowiew 1974: 190).

Krzepnące państwo zmierzało do wszechwładztwa we wszystkich sferach ludzkiej działalności. Proces przekuwania „materiału ludzkiego epoki kapitalistycznej” w homososa doczekał się opracowania nowych metod. Ich podstawę stanowiły dwa główne wektory - byt i świadomość (gdzie zmiana bytu - zgodnie z regułą Marksową - miała automatycznie prowadzić do zmiany świadomości). By przekształcić byt, trzeba było najpierw zburzyć stary system i w tym celu najsilniejszy atak został wymierzony w społeczeństwo. Główne ciosy spadły na to, co decyduje o więzach międzyludzkich tworzących podstawową tkankę społeczną (rodzina, język, religia, pamięć historyczna). Postrzegano w nich bowiem rzeczywiste zagrożenie dla wszechdominacji władzy państwowej.

Zamiatin w 1920 roku wskazywał, że „strach, nienawiść, miłość do Dobroczyńcy, manipulacja pamięcią, władza nad słowem i pełna kontrola nad prywatnym życiem" (Heller 1988: 93-94), jak również odpowiednio skonstruowana i pielęgnowana mitologia, literatura i sztuka muszą zmienić człowieka i zbliżyć go do założonego ideału.

\section{Antoni Siemionowicz Makarenko i jego pedagogika}

Makarenko rozpoczął pracę jako pomocnik nauczyciela w wiejskiej szkółce mając zaledwie 15 lat. Zachęcony pierwszymi sukcesami, w 1914 roku podjął studia w Instytucie Nauczycielskim w Połtawie, który ukończył w 1917 roku ze złotym medalem. Do pracy nauczycielskiej wrócił w pierwszych miesiącach rewolucji, kiedy dawały o sobie znać wypierające się wzajemnie przeciwstawne koncepcje wychowania (Sobczak 1980: 227). Jak pisze Kamiński: „Październikowa rewolucja komunistyczna (...) zastała w rosyjskim świecie pedagogicznym następującą sytuację: $z$ jednej strony - tradycyjna carska, duchem herbartowskim owiana szkoła, z drugiej - dwa nurty usiłujące ją podważyć (...): nurt pedagogiki eksperymentalnej i nurt »swobodnego wychowania «" (Kamiński 1948: 13-14).

Podczas gdy inni radzieccy pedagodzy (Krupska, Szacki, Błoński) koncentrowali się na wprowadzaniu teorii marksistowskiej do pedagogiki i tworzeniu systemu pedagogicznego „na miarę” Kraju Rad, Makarenko przez 16 lat prowadził własny eksperyment pedagogiczny z tzw. biezprizornymi; stworzył twórcze pedagogiczne laboratorium (Lewin 1960: 77). Pisał: „Wszyscy wiemy doskonale, jakiego powinniśmy wychować człowieka,

\footnotetext{
1 Homosos - charakterystyczny dla nowomowy skrót od homo sovieticus.
} 
orientuje się w tym każdy piśmienny, uświadomiony robotnik, dobrze wie każdy członek partii. Cała trudność tkwi więc nie w zagadnieniu, co trzeba zrobić, lecz jak zrobić. A to jest zagadnienie techniki pedagogicznej" (Makarenko 1955: 576), którą - jak uważał wyprowadzić można jedynie z doświadczenia. Zgodnie z tym, swoją działalność pedagogiczną Makarenko podporządkował logice działań wychowawczych, nie zaś sugestiom władz czy oficjalnie uznanych pedagogów, czym naraził się radzieckiemu „olimpowi” pedagogicznemu. Do ostatnich lat życia ,jego nowatorska działalność stanowiła przedmiot ostrych ataków" (Lewin 1969: 6), co Lewin wyjaśnia tym, że jego poglądy i działania „wyprzedzały pod wieloma względami współczesną mu praktykę i teorię wychowania" (Lewin 1969: 6-7).

Z drugiej strony, Kamiński zauważa, że „(z)jawisko Makarenki (...) polega na wyjątkowo trafnym odczuciu ustroju, w którym żyje i pracuje oraz zbudowaniu takiego systemu wychowawczego, który jest idealnym wyrazem tego ustroju" (Kamiński 1948: 31-32) i stąd: „,...) pedagogika Makarenki - jest pe da g o gi ką walki. Jest kształtowaniem s ow i e cki e g o c złow i e k a w myśleniu i działaniu. Jest wdrażaniem do k o lektyw ny ch form życia sowieckiego" (Kamiński 1948: 32-33).

Zdaniem Kotłowskiego „(w) osobowości Makarenki widzimy wcielenie trudnej, ale heroicznej epoki, porywającej się na zmianę łożysk rzek syberyjskich i tworzenie nowych mórz (...). Makarenko Tworzy nowego człowieka w trudzie i tytanicznej walce, jest demiurgiem nowych osobowości spalającym się w prometejskiej męce (...). Makarenko siłą macierzyńskiego wprost uczucia i oddania czynnie uczestniczy w procesie stawania się nowego typu zbiorowości, cierpi razem z nią i triumfuje, kocha nawet wtedy, kiedy nieopatrznie krzywdzi" (Kotłowski 1959: 132).

„Mój system zwykły, sowiecki” - zwykł mawiać Makarenko, a stwierdzenie to najdobitniej ujmuje harmonijną relację, w jakiej postrzegał swój system wychowania i system społeczno-polityczny państwa (Kotłowski 1959: 32-33).

W twórczości pisarskiej Makarenki szczególne miejsce zajmuje Kniga dla roditie$l e j$ - „poradnik” dla rodziców poświęcony wychowaniu rodzinnemu i towarzyszące mu odczyty o wychowaniu, oraz radiowe przemówienia na temat wychowania w rodzinie. Trzeba pamiętać, że nowa władza, nowe ustawodawstwo i nowa obyczajowość Kraju Rad traktowały rodzinę z wyraźną rezerwą, jako „pierwotną formę niewolnictwa” i „,burżuazyjny przeżytek" (Heller 1988: 167). Radzieccy ideolodzy skrzętnie też podchwycili doniesienia ówczesnych socjologów mówiące o rozkładzie rodziny za sprawą zaniku rodzinnych warsztatów pracy i form produkcji, upowszechniania się szkoły, zróżnicowania zawodowego członków rodzin, rozwoju środków komunikacji sprzyjającego rozproszeniu członków rodziny, proletaryzacji mieszkańców miast i wsi itp. W rzeczywistości porewolucyjnej Rosji zjawiskom tym towarzyszyło jeszcze jedno - „bezprizorni”, czyli dzieci/młodzież, które w rewolucyjnej zawierusze straciły rodziców. Analizowanie przez Makarenkę źródeł bezprizornosti doprowadziło go do problemu rodziny. Wychodząc z założenia, że istotnym spoiwem rodziny pozostaje więź duchowa, uczucia miłości i przywiązania oraz wydawanie na świat i wychowywanie dzieci, Makarenko był tym 
pedagogiem, który najwcześniej postawił problem opieki nad rodziną i uczynienia z niej „bazy wychowawczej”.

W Knigie dla roditielej Makarenko udziela rodzicom szeregu sugestii, których punktem wyjścia jest konstatacja, że chociaż rodzina może i powinna być naturalnym środowiskiem wpływów wychowawczych, to przecież „rodziny bywają dobre i złe”, zatem nie można liczyć na to, iż rodzina wychowa dziecko jak należy. Na tej przesłance Makarenko opiera wniosek, że wychowanie rodzinne powinno być organizowane, a organizatorem tego wychowania powinna być szkoła, jako agenda wychowania państwowego. Postulat organizowania i kierowania wychowaniem rodzinnym szkoła ma realizować ucząc rodziców postępowania wychowawczego (Makarenko 1956).

\section{Retoryka Makarenkowskich odczytów}

Jewgienij Zamiatin charakteryzując tzw. „Jedyne Państwo” w powieści My zauważył, że mieszkańcy państwa przyszłości mówią specjalnym językiem, w którym słowa mogą oznaczać to, czego chce państwo (Zamiatin, 1967). Podobny zabieg opisuje George Orwell w Roku 1984 pokazując, że język może być najpotężniejszą bronią państwa służącą wykuciu nowego człowieka. Manipulowanie przy języku ma zwykle dwa zasadnicze cele: zdobycie „środków wyrazu dla światopoglądu i myśli, które należy żywić” oraz „uniemożliwienie innych sposobów myślenia" (Orwell bd: 142). W ten sposób nowy język pozostaje $\mathrm{z}$ jednej strony środkiem porozumiewania się, z drugiej zaś narzędziem opresji, wiodącej do ukształtowania/samokształtowania się nowego człowieka.

Jak wspomniano na wstępie, podstawę charakterystyki wypowiedzi Makarenki stanowi Książa dla rodziców. Odczyty o wychowaniu dzieci. Przemówienia na temat wychowania w rodzinie, w której zostały zidentyfikowane zabiegi retoryczne, stanowiące egzemplifikację urządzania rodziny (binarne opozycjonowanie dobra i zła, wykorzystanie negatywnych wzorców językowych, odwracanie znaczeń, zastosowanie metafory i porównania).

Najlepiej widocznym zabiegiem jest dostrzegalne od pierwszej do ostatniej strony tekstu jego ideologiczne uwikłanie oraz wynikające zeń ideologicznie zabarwione przesłanie adresowane do rodziców, skonstruowane na binarnym opozycjonowaniu dobrego i złego, słusznego i niesłusznego myślenia i działania. Dobre, słuszne jest skojarzone z nowym modelem rodziny radzieckiej pojmowanej jako kolektyw (Makarenko 1956: 43), natomiast złe, niesłuszne - z przedrewolucyjnym modelem rodziny burżuazyjnej. Analogicznie: ideologicznie poprawnym wzorcem człowieka jest istota o mentalności kolektywnej, a modelem ideologicznie niepożądanym - człowiek burżuazyjny/kapitalistyczny.

Innym zabiegiem retorycznym jest osadzanie wypowiedzi autora odczytów na negatywnych wzorcach językowych (por. Rosenberg 2009), których użycie skłania do konstruowania nieumotywowanych założeń oraz formułowania uproszczonych sądów i generalizacji. Przykładem użycia takich negatywnych wzorców jest określenie pozakolektywnego wychowania w rodzinie jako „tresury domowej”. Słowo „tresura” kojarzone jest zwykle $\mathrm{z}$ wywoływaniem określonych zachowań u zwierząt za pośrednictwem bazującego na 
instynktach kojarzenia bodźców. Zestawienie go z wychowaniem domowym wywołuje negatywne skojarzenia w odniesieniu do wcześniej pozytywnie waloryzowanego procesu.

Kolejnym zabiegiem jest orwellowska praktyka odwracania znaczeń, które w kulturze mają już określone identyfikacje semantyczne. Przykładem tego rodzaju zabiegu jest użycie przez Makarenkę określenia „domowe więzienie” na oznaczenie rodziny. Więzienie jest bowiem kojarzone $\mathrm{z}$ odebraniem wolności, natomiast rodzina $\mathrm{z}$ bezpieczeństwem i bliskością. Zestawienie tych terminów w jednej frazie powoduje dezorientację semantyczną i umożliwia przekonstruowanie znaczeń, przypisywanych im pierwotnie oraz odczuć z nimi wiązanych.

Metafora jest następnym środkiem retorycznym, zastosowanym w odczytach Makarenkowskich. „Nasze dzieci rozkwitają na żywym pniu naszego życia; to nie bukiet, to piękny sad jabłoni. (...) A kiedy w waszym sadzie pojawią się gąsienice, weźcie zieleń paryską. Nie bójcie się, pokropcie trochę, nawet jeśli kwiatom będzie trochę nieprzyjemnie" (Makarenko 1956: 19-20). Metafora „ogrodnicza” była pedagogice znana na długo przed Makarenką, ale w jego odczytach zastosowana została ona w szczególny sposób; eksponowana jest bowiem nie tyle jako metoda „usuwania chwastów”, ale jako praktyka leczenia. Jak nietrudno zauważyć - leczenia opartego na zastosowaniu drastycznych środków.

Jeszcze innym zabiegiem jest porównanie, które Makarenko często wykorzystuje w swoich odczytach. Przykładem tego zabiegu jest fragment: „nie ma u nas miejsca na (...) żadne niepowodzenia wychowawcze, na żaden procent braków, nawet gdyby stanowiły one setne części ułamka!” (Makarenko 1956: 10). Dziecko jest w nim porównywane do produktu, natomiast wychowanie do procesu produkcyjnego. Jest to bardzo śmiałe porównanie, nieczęste na gruncie pedagogiki, która stara się nie czynić porównań między człowiekiem (dzieckiem) a rzeczą.

Szkicowo jedynie wskazane zabiegi retoryczne odsłaniają związek pedagogiki Makarenki z polityką państwa sowieckiego (w urządzaniu ówczesnej populacji). Niekiedy te odniesienia są formułowane wprost, jak we fragmencie: ,księgi i czyny rewolucji - oto gotowa już pedagogika nowego człowieka" (Makarenko 1956: 9), w którym Makarenko bezpośrednio odnosi się do aktualnej polityki i praktyki państwa sowieckiego jako źródła konceptualizacji pedagogicznych. W innych miejscach nawiązuje on raczej do praktyki życia w Rosji sowieckiej, niż wprost do ideologii państwowej: „moralna głębia i zgodność praktyki życiowej kolektywu rodzinnego stanowią zupełnie niezbędny warunek radzieckiego wychowania" (Makarenko 1956: 46-47), zaś tworzywem do takiego wychowania, ma być „życie radzieckie w jego wszystkich różnorodnych przejawach” (Makarenko 1956: 19).

Wychowanie kolektywne w kolektywnym społeczeństwie jest osadzone w polityce deprecjonowania roli indywiduum, również w wymiarze wychowawczym: „,człowiek radziecki nie może być wychowywany przez bezpośredni wpływ jednego człowieka, choćby ten miał największe zalety. Wychowanie jest to proces społeczny w najszerszym tego słowa znaczeniu” (Makarenko 1956: 18). Makarenko uważa, że „bezmyślne i beznadziejne są usiłowania niektórych rodziców wyłączenia dziecka spod wpływów życia i zastąpienia wychowania społecznego indywidualną tresurą domową. I tak czeka ich niepowodzenie: 
albo dziecko wyrwie się z domowego więzienia, albo wychowają potwora" (Makarenko 1956: 15). Dowodzi, że „o powodzeniu wychowania w rodzinie decyduje aktywne, stałe, całkowicie świadome spełnianie przez rodziców ich obywatelskiego obowiązku względem radzieckiego społeczeństwa" (Makarenko 1956: 21-22).

\section{Makarenkowskie odczyty w optyce Foucaultowskiej kategorii urządzania}

Podjęta przez nas próba ulokowania analizy Makarenkowskich odczytów dla rodziców w optyce Foucaultowskiej kategorii urządzania jest przedsięwzięciem dość ryzykownym, ponieważ we współczesnej pedagogice dorobek M. Foucaulta jest zwykle wykorzystywany do badania społeczeństw ponowożytnych, a nie społeczeństw totalitarnych ubiegłego wieku. Wydaje się jednak, że argumentem na rzecz jego realizacji może być nasze przekonanie o tym, że pedagogika Makarenkowska stanowi rodzaj teorii i praktyki splecionej z szerzej rozumianą polityką państwa wobec jednostki i populacji. Tę zaś kwestię trudno już obecnie podejmować bez uwzględnienia perspektywy Foucaultowskiej, nie ryzykując oglądu radykalnie spłaszczonego i niepełnego.

W interpretacji M. Foucaulta urzadzanie z perspektywy historycznej jest rezultatem procesów, związanych z poprzedzającym ZSRR pojawieniem się populacji jako bytu politycznego, ekonomicznego i naukowego, który można problematyzować, opisywać, tworzyć na jego temat wiedzę i wreszcie - którym trzeba zarządzać. Samo pojęcie jest przez niego interpretowane jako trzyelementowy zbiór: po pierwsze ,instytucji, procedur, analiz, refleksji i taktyk umożliwiających sprawowanie (...) władzy nakierowanej przede wszystkim na populację, władzy opierającej się na ekonomii politycznej jako pewnej formie wiedzy i posługującej się zasadniczo urządzeniami bezpieczeństwa" (Foucault 2010: 127), po drugie - jako „pewną linię siły, która (...) prowadzi do dominacji tej formy władzy, którą można by nazwać »rządzeniem«, nad wszelkimi innymi formami, zwłaszcza nad władzą suwerenną i dyscypliną” (Foucault 2010: 127), i po trzecie - jako „proces, albo raczej wynik procesu, za sprawą którego (...) państwo (...) zostaje (...) poddane »zasadzie rządów«" (Foucault 2010: 127).

Urządzanie obejmuje zatem ,zestaw specyficznych warunków instytucjonalnych, proceduralnych i dyskursywnych, które umożliwiają sprawowanie władzy nad populacją" (Ostrowicka 2015: 101), łatwo dający się odnieść do praktyk sowieckiego państwa. Zainteresowanie populacją stanowi $\mathrm{w}$ dorobku Foucaulta efekt przesunięcia $\mathrm{w}$ badaniach z kwestii mikrofizyki władzy na kwestie makrofizyki rządzenia, dotyczącej strategicznej roli państwa w zarządzaniu populacją. Z kolei konkretny model rządzenia państwem Foucault opisuje jako szczególną sztukę rządzenia, czyli właśnie urządzanie (Ostrowicka 2015: 100). Przedmiotem owego rządzenia jest jednak zawsze „populacja, nie zaś indywidua, serie, grupy, wielość indywiduów. Ta ostatnia ma jedynie służyć jako narzędzie, warunek, przystanek $w$ dążeniu do określonych celów na poziomie populacji” (Foucault 2010: 64). Z tej perspektywy ekonomia polityczna jako rodzaj wiedzy o tej populacji, zróżnicowane techniki władzy oraz różnorakie urządzenia społeczne stanowią wskaźniki 
urządzania, urządzania rozumianego jako formuła odpowiadająca wcześniejszej koncepcji władzy-wiedzy M. Foucaulta, odnosząca się do populacji naczelna zasada obejmująca wszystkie typy praktyk władzy (Czyżewski 2009).

W kontekście kategorii urządzania, odczyty Makarenkowskie, w których kluczowym terminem pedagogicznym (punktem wyjścia i punktem dojścia, celem i metodą) jest kolektyw, okazują się być składową opisanego w pierwszej części tekstu wielkiego projektu politycznego, jakim było budowanie nowego sowieckiego świata. Z kolei konstruowanie nowego modelu człowieka o mentalności kolektywnej okazuje się być częścią polityki państwa sowieckiego (urządzania rodziny), zmierzającej do zarządzania populacją.

$\mathrm{Na}$ analitykę urządzania składa się między innymi ,retoryka, słownictwo i procedury produkcji »prawdy«" (Dean, 2010, za: Ostrowicka 2015), które w kontekście odczytów Makarenkowskich zostały poddane namysłowi w drugiej części tekstu. Stanowią one (jako to, co wypowiedziane) wraz z infrastrukturą instytucjonalną i organizacyjną (czyli tym, co niewypowiedziane), jak pisze M. Foucault „elementy dyspozytywu”, czyli urządzenia lub zastosowania wiedzy.

W interpretacji H. Ostrowickiej dyspozytyw (urządzenie) nie jest ,zbiorem elementów autonomicznych wobec siebie, lecz układem relacji między nimi. Ta kompozycja elementów dyskursywnych i niedyskursywnych pełni funkcję mechanizmu wytwarzającego wiedzę o świecie, reprezentacje zawierające formy racjonalności, legitymizujące określone praktyki społeczne” (Ostrowicka 2015: 70). Dyspozytyw jako „strategiczne zespolenie (układ, sieć, ansambl) elementów dyskursywnych i niedyskursywnych (np. rozwiązań instytucjonalnych i organizacyjnych) (Ostrowicka 2015: 135), stanowi zatem rodzaj mechanizmu aktualizowania się urządzania. Równocześnie „,dispositif to społeczny aparat, rama lub matryca, utworzona przez dyskursywne i instytucjonalne praktyki, których przecinające się linie tworzą odrębną historyczną i społeczno-polityczną rzeczywistość" (Milchman, Rosenberg 2006: 268), w tym przypadku sowieckiego państwa.

„Urządzenie jest elementem urządzania władzy, który ma za zadanie opanować daną, ważną ze względu na szersze strategie dominującej racjonalności rządzenia, rzeczywistość. Jest więc ważną ze względu na urządzanie władzy problematyzacją dostarczającą wiedzy i rozwiązań technicznych dla określonego sposobu kierowania kierowaniem się podmiotów" (Chutorański 2013: 131). W kontekście analizowanej problematyki ową rzeczywistością jest rodzina i dokonujące się w niej procesy wychowawcze. Jak pisze Makarenko, „wszyscy wiemy doskonale, jakiego powinniśmy wychować człowieka (...). Całą trudność tkwi więc nie w zagadnieniu, co trzeba zrobić, lecz jak zrobić. A to jest zagadnienie techniki pedagogicznej" (Makarenko 1955: 576). Tę trudność Makarenko zdaje się sprawnie pokonywać, ponieważ jego odczyty w całości zostały zogniskowane na bazowym dla wychowania doświadczeniu życia w społeczeństwie komunistycznym. Życie w kolektywie dostarczać ma owej techniki pedagogicznej, czyli wiedzy typu ,jak”, a ideologia państwowa wiedzy typu „co”.

Jak wskazuje M. Foucault „dyspozytyw aktualizuje rozum urządzający w procesach »wytwarzania podmiotów« (obiektywizacji podmiotu)" (Ostrowicka 2015: 135), wi- 
doczny w kontekście skrajnie zideologizowanego charakteru odczytów. Wglądu w ową aktualizację „rozumu urządzającego” dostarczyła analiza stylu wypowiedzi ich autora, osadzona na styku pedagogicznej konceptualizacji polityki państwa dotyczącej podmiotu i populacji oraz splecionych z nią pedagogicznych praktyk. Jak bowiem pisze M. Chutorański kategorię urządzenia „można odnieść do tego, co zwykle nazywamy teorią i praktyką pedagogiczną" (Chutorański 2013: 126).

\section{Literatura}

Bucharin N. Programma RKP (poczatek 1917 r.).

Chutorański M. (2013), Pojęcie i konteksty wychowania w pracach Michela Foucaulta. Wrocław, Wydawnictwo Naukowe DSW.

Czyżewski M. (2009), Między panoptyzmem a „rządomyślnościa”. Uwagi o kulturze naszych czasów. „Kultura Współczesna”, 2.

Dean M. (2010), Governmentality: Power and rule in modern society. London, Sage.

Foucault M. (2010), Bezpieczeństwo, terytorium, populacja. Wykłady w Collège de France 19771978. Warszawa, Wydawnictwo Naukowe PWN.

Heller M. (1988), Maszyna i śrubki. Jak hartowat się człowiek sowiecki. Paryż, Instytut Literacki.

Kamiński A. (1948), Pedagogika Antoniego Makarenki. Warszawa, Robotnicze Towarzystwo Przyjaciół Dzieci.

Kotłowski K. (1959), Socjologizm pedagogiczny Durkheima i jego krytyka. „Studia Pedagogiczne, 7.

Lewin A. (1960), Makarenko. Konfrontacje pedagogiczne. Warszawa, PZWS.

Makarenko A. (1955), Dzieła, Tom I: Poemat pedagogiczny. Warszawa, PZWS

Makarenko A. (1956), Książka dla rodziców. Odczyty o wychowaniu dzieci. Przemówienia na temat wychowania w rodzinie. Warszawa, PZWS.

Milchman A. Rosenberg A. (2003), Eksperymenty w myśleniu o Holocauście. Auschwitz, nowoczesność i filozofia. Warszawa, Wydawnictwo Scholar.

Orwell G. Rok 1984. The Estate of the Late Sonia Brownell Orwell, https://stopsyjonizmowi.files. wordpress.com/2012/09/rok-1984-george-orwell.pdf (dostęp: 12.11.2016).

Ostrowicka H. (2015), Przemyśleć z Michelem Foucaultem edukacyjne dyskursy o młodzieży. Dyspozytyw i urzadzanie. Kraków, Oficyna Wydawnicza Impuls.

Rosenberg M.B. (2009), Porozumienie bez przemocy. O języku serca. Warszawa, Wydawnictwo Czarna Owca.

Sobczak J. (1980), Niektóre przykłady wykorzystania doświadczeń i myśli A.S. Makarenki we wspótczesnej pedagogice. „Studia Pedagogiczne”, 6.

Sowietskije ludi (1974), praca zbiorowa. Moskwa.

Zamiatin J. (1967), My. Nowy Jork, Interlanguage Literary Associates.

Zinowiew A. (1974), Wstęp: Homo sovieticus, W: Sowietskije ludi (praca zbiorowa). Moskwa. 